laboratory conditions. Acta theriol., 9: 371-373. K r u k H., 1972: Surplus killing by carnivores. J. Zool., Lond. 166: 233-244. Loxton R. G., R a f f a elli D. \& B egon A., 1975: Coprophagy and the diurnal cycle of the common shrew, Sorex araneus. J. zool., Lond., 177: 449-453. M a s e r C. \& H o o v e n E. F., 1974: Notes on the behavior and food habits of captive pacific shrews, Sorex pacificus pacificus. Northwest Sci., 48, 2: 81-95. O h o t in a M. V., 1974: Morfo-ekologičeskie osobennosti različnych vidov burozubok (Sorex Insectivora), obuslovlivajuščie vozmożnost' ih sovmestnogo suščestvovanija. [In: Ohotina M. V. ed. »Fauna i ekologija nazemnyh pozvonočnyh juga dal'nego vostoka SSSR «]. 42-57. Akad. Nauk. SSR. Vladivostok. P e r nett a J. C., 1976: Diets of the shrews Sore.x araneus L. and Sorex minutus L. in Wytham grassland. J. Anim. Ecol. 45: 899912. Sk a rén U. 1972: Fluctuations in small mammal populations in mossy forests of Kuhmo, eastern Finland, during eleven years. Ann. Zool. Fennici 9: 147 -151. Skarén U. \& Ka i kusal o A., 1966: Suomen pikkunisäkkäät. Otava: 1-227. Helsinki. Spannhof L., 1952: Spitzmäuse. Die Neue Brehm-Bücherei: 1-43. Leipzig. Stroganov S., 1957: Zveri Sibiri. Nasekomojadnye. Izd. Akad. Nauk. SSSR: 1-267. Moskva. Vo g e l P., 1974: Kälteresistenz und reversible Hypothermie der Etruskenspitzmaus (Suncus etruscus, Soricidae, Insectivora). Z. Säugetierkunde, 39, 2: 78-88. Wołk E., 1969: Body weight and daily food intake in captive shrews. Acta theriol., 14, 4: 35-47. W o $1 \mathrm{k} \mathrm{K}$., 1976: The winter food of the European water-shrew. Acta theriol., 21, 6: 117-129.

Accepted, June 28, 1977.

\title{
A Comparison of Number of Embryos and Measurements of Microtus montebelli in Two Types of Habitats
}

Porównanie wymiarów i liczby embrionów u Microtus montebelli żyjących w dwu różnych środowiskach

\section{Yukibumi KANEKO}

Kaneko, Y., 1978: A comparison of number of embryos and measurements of Microtus montebelli in two types of habitats. Acta theriol., 23, 6: $140-143$ [With 3 Tables \& 1 Fig.]

External and cranial measurements and number of embryos were compared in the Japanese field vole (Microtus montebelli) between neighboring October populations in different habitats, namely cultivated land and young plantation. It is concluded that habitat differences between the two populations caused the morphological differentiation in males $(H \& B L, B W, C B L, Z W$ and $C-Z)$, while these differences had little effect on female measurements but brought about variation in the average number of embryos recorded.

[Biol. Inst., Fac. Educ., Kagawa Univ., Takamatsu 760, Japan.]

The Japanese field vole, Microtus montebelli ( $\mathrm{M}$ il ne-Edwards, 1872), is found on Honshu, Kyushu and Sado Islands, and inhabits mainly cultivated land and young plantation. So far as we know, nothing has been reported on the variation of this vole in relation to difierences in habitat. The present paper makes a comparison of external and cranial measurements and number of embryos between neighboring October populations in two habitats in the northeastern part of Hiroshima Prefecture, Honshu. 
Trapping survey was carried out from October 14 to 17, 1972. The trapping site of rice field (A), which consited of fallows and footpaths, was located on the folds of the Chugoku Mountains in Iinseki District. The elevation of the site was $490 \mathrm{~m}$ above the sea-level. The plantation (B) consisted of five years old the Japanese cypress, Chamaecyparis obtusa, spaced out at approximately $3 \mathrm{~m}$ intervals in grassland that was conventionally harvested by hand for hay. The area of the plantation was roughly $4.5 \mathrm{~km}$ apart from site-A, and lay on the slope of a low mountain in Kōnu District. The altitude of area-B was about $640 \mathrm{~m}$.

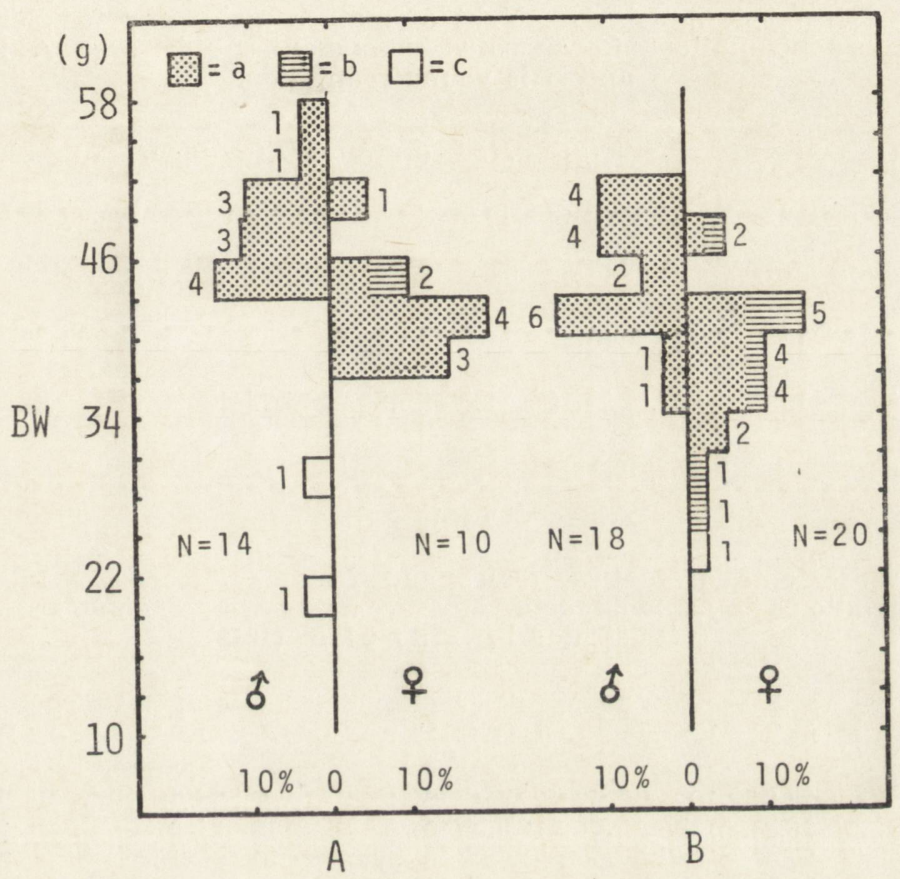

Fig. 1. Percentage histograms showing the frequency of the body weight (BW) and reproductive condition in Microtus montebelli in neighboring October popuiations. The study area $\mathrm{A}$ is rice field and $\mathrm{B}$ is young plantation. Body weight subtracting the weight of embryos was used as that of each pregnant female. Numbers at side of columns refer to the size of the group. The method of estimation of breeding condition was described in $\mathrm{K}$ a n e k o (1976).

$a=$ male-mature; female-pregnant, $b=$ female-nursing just after parturition, $c=$ male-immature; female-immature.

All the specimens were snap-trapped. In site-A, traps were set within the runway of the most promising Microtus habitat (243 trap-nights). In area-B, a 143-station grid, composed of 11 rows and 13 lines spaced $5 \mathrm{~m}$ apart, was established. 
Breeding condition of the vole was estimated by autopsy method, which was described in $\mathrm{K}$ a neko (1976). Body weight subtracting the weight of embryos was used as that of each pregnant female. Measurements were taken as described and illustrated in $\mathrm{K}$ a n e k o (1978).

The histograms of body weight $(B W)$ in two populations closely resembled each other in pattern (Fig. 1). Since the distribution of body weight was nearly monomodal with many pregnant females and small numbers of young, the breeding season of the two populations could

Table 1

External measurements and body weight of mature males and females (mean $\pm \mathrm{SE}$ ) in two October populations in Microtus montebelli. Study area A is rice field and $\mathrm{B}$ is young plantation.

\begin{tabular}{lccccccc}
\hline Study & area & $\mathrm{N}$ & $B W(\mathrm{~g})$ & $H B L(\mathrm{~mm})$ & $T L(\mathrm{~mm})$ & $H F L(\mathrm{~mm})$ & $E L(\mathrm{~mm})$ \\
\hline Males & $\mathrm{A}$ & 12 & $48.33 \pm 1.14$ & $125.76 \pm 1.51$ & $38.74 \pm 1.18$ & $17.89 \pm .13$ & $11.70 \pm .22$ \\
& $\mathrm{~B}$ & $18(*=17)$ & $44.78 \pm 1.02$ & $120.68 \pm 1.22$ & $38.66 \pm .89$ & $* 17.76 \pm .14$ & $11.72 \pm .19$ \\
\hline \multirow{2}{*}{ Females } & $\mathrm{A}$ & 10 & $41.88 \pm 1.24$ & $116.25 \pm 1.52$ & $36.32 \pm .84$ & $17.72 \pm .17$ & $11.70 \pm .16$ \\
& B & 19 & $37.81 \pm 1.19$ & $114.45 \pm 1.30$ & $37.37 \pm .66$ & $17.73 \pm .18$ & $11.81 \pm .19$ \\
\hline
\end{tabular}

Table 2

Cranial measurements of mature males and females (mean $\pm S E$ ) in neighboring October populations of $M$. montebelli. Measurements were taken as described and illustrated in Kaneko (1978)

\begin{tabular}{|c|c|c|c|c|}
\hline & \multicolumn{2}{|c|}{ Males } & \multicolumn{2}{|c|}{ Females } \\
\hline & A $(N=12)$ & $\mathrm{B}(\mathrm{N}=15)$ & A $(N=9)$ & B $(\mathrm{N}=19)$ \\
\hline$C B L(\mathrm{~mm})$ & $2824 \pm .16$ & $27.66 \pm .16$ & $26.92 \pm .15$ & $2682 \pm .21$ \\
\hline$Z W(\mathrm{~mm})$ & $1651 \pm .14^{1}$ & $15.85 \pm .10$ & $1562 \pm .07$ & $15.58 \pm .15$ \\
\hline$C-Z(\mathrm{~mm})$ & $22.49 \pm .13$ & $21.99 \pm .13$ & $21.49 \pm .12$ & $21.41 \pm .15$ \\
\hline$C-M L(\mathrm{~mm})$ & $17.77 \pm .11$ & $17.42 \pm .12^{2}$ & $1692 \pm .07$ & $16.89 \pm .13$ \\
\hline$I-M^{3}(\mathrm{~mm})$ & $16.95 \pm .11$ & $16.75 \pm .07^{3}$ & $1644 \pm .11$ & $16.51 \pm .13$ \\
\hline Dias (mm) & $8.58 \pm .07$ & $848 \pm .09^{4}$ & $8.16 \pm .06$ & $8.17 \pm .08$ \\
\hline$M L(\mathrm{~mm})$ & $6.10 \pm .06$ & $6.09 \pm .05$ & $5.97 \pm .04$ & $6.17 \pm .05$ \\
\hline
\end{tabular}

be regarded as as being synchronized. Therefore, it is clear that the two populations were the same in age composition.

The mean sizes and weight of mature animals were larger and heavier in population A than in population B (Table 1 and ?). There were statistically significant differences between the two populations in male sizes and weight such as $H \& B L, B W$, and $Z W$ (t-test, $p<0.001)$, and $C B L$ and $C-Z$ (t-test, $0.01<p<0.02$ ). There was no differences in females 
in the measurements described above by the statistical test. The number of embryos was found to be significantly larger in populations $\mathrm{A}$ than in population B ( $t$-test, $p<0.001$ ) (Table 3$)$.

Since both populations were considered to be the same in age composition, it is concluded that habitat differences between the two populations caused the morphological differentiation in males, while these

\section{Table 3}

Number of embryos in neighboring October populations of $M$. montebeli. Further explanations are given in Table 1.

\begin{tabular}{|c|c|c|c|c|c|c|c|}
\hline \multirow{2}{*}{ Study area } & \multirow{2}{*}{$\mathrm{N}$} & \multicolumn{5}{|c|}{ No. of embryos } & \multirow{2}{*}{ Mean $\pm \mathrm{SE}$} \\
\hline & & 23 & 4 & 5 & 6 & 7 & \\
\hline $\mathrm{A}$ & $\begin{array}{r}9 \\
12\end{array}$ & 1 & 4 & $\begin{array}{l}3 \\
3\end{array}$ & 3 & 3 & $\begin{array}{l}6.00 \pm .29 \\
3.75 \pm .28\end{array}$ \\
\hline
\end{tabular}

differences in habitat had little effect on female measurements but brought about variation in the average number of embryos recorded.

I wish to thank to $\mathrm{Mr}$. J. Kingdon and Profesor E. W. Jameson, Jr. for reading and criticizing the manuscript.

\section{REFERENCES}

Kaneko Y., 1976: Reproduction of Japanese field voles, Microtus montebelli (Milne-Edwards), at Iwakura, Kyoto, Japan. Jap. J. Ecol., 26: 107-114. K a n e k o Y., 1978: Seasonal and sexual differences in absolute and relative growth in Japanese field voles, Microtus montebelli. Acta theriol., 23, 4: 75-98.

Accepted, March 30, 1977. 